\title{
NO ORDINARY LOVE: ORDINARY PEOPLE BY DIANA EVANS
}

\begin{abstract}
This paper will focus on the links between black identities and urban spaces in the postcolonial context by analysing Diana Evans's third novel published in 2018. Ordinary People charts the waning love in a couple coping with their small children, family duties, passion, infidelity, and careers. While delving into black British and mixedrace identities in the urban milieu, the author casts a special light on a neighbourhood of London, Crystal Palace, and its enchanting energy, culture, even crime. The paper will explore how the postcolonial city is reflecting the relationship between the main characters in the novel.
\end{abstract}

Key words: postcolonial London, black British identity, urban narrative

\section{Mixtape}

Diana Evans borrows the title of her novel from the eponymous single written and performed by John Legend, an R\&B singer, from his debut album released in 2004 and the title of this paper combines it with another song, No Ordinary Love, a 1992 hit by Sade. "I wanted to write a book about contemporary London" Diana Evans said in an interview for The Guardian and added: "Black people, thirtysomethings, couples. Part of what I'm trying to do is to make us visible, because we aren't visible in imagery. Writing about London, I'm trying to own London" (Allardice: 2018). London is significant as urban narrative for the author, since all three novels written by her are set in London, the first one in Neasden in the northern part of the city, the second in west London and the latest novel takes place in a southern neighbourhood. Similarly to her debut, $26 a$ (2005), which begins with the Royal Wedding of the Prince and Princess of Wales in 1981 and ends with Lady Di's funeral in 1997, Diana Evans bookended Ordinary People by real events: it opens with the election of Barack Obama in late 2008 and the ending coincides with the news of Michael Jackson's death in the summer of 2009. When discussing the new urbanism in context, Ash Amin and Nigel Thrift consider that there are "... three strong metaphors in the tradition of everyday urbanism. The first is transitivity, which marks the spatial and temporal openness of the city. The second captures the city as a place of manifold rhythms, forged through daily encounters and multiple experience of time and space. The third notes the city

"College of Tourism, Bulevar Zorana Đinđića 152a, 11070 Belgrade, Serbia; e-mail: foxlinden@gmail.com 
as footprints: imprints from the past, the daily tracks of movement across, and links beyond the city" (Amin and Thrift 2002: 9, original emphasis). There is interconnection of the various spatial and temporal levels of colonial and postcolonial London in Diana Evans's novel explored in this paper. The rhythms based on daily experience of the characters are also supported by the music soundtrack that accompanies many events in the novel.

\section{Re: construction}

The main location in the novel's cityscape is the part of London named Crystal Palace. The Crystal Palace was originally built to house the Great Exhibition in 1851. The Victorian structure consisting of cast iron and sheet glass celebrated the achievements of the Industrial Revolution and the British Empire and numerous people flocked to admire it. After the exhibition, it was relocated across the Thames, from Hyde Park to a park in South East London and eventually it was destroyed by fire in the 1930s. However, the surrounding area, including a Tube stop, still bears its name. The description of Crystal Palace neighbourhood in London is already given in the first paragraph of the novel: "They lived near the park, where the transmitting tower loomed up towards the heavens like a lesser Eiffel, stern and metallic by day, red and lit up by night, overlooking the surrounding London boroughs and home counties below, harbouring in the green land at its feet the remains of the former glass kingdom - the lake, the maze, the broken Greek statues, the eroded stone lions, and the dinosaurs made of old science" (Evans 2018: 1). Setting the scene, the sentence refers to the fall of the British Empire from the middle of the $20^{\text {th }}$ century, and its decline that ensued the destruction of Crystal Place. It can be detected in the words used in the extract: the 'former glass kingdom' as the end of the long colonial era that was about to break, it is made of glass that underlines its imminent shattering to shreds, 'the lake and maze' as symbols of medieval castles and their moats and therefore, kings and queens again, 'Greek statues' as something belonging to ancient civilisations. Furthermore, lions as the British heraldic symbols appear worn down, without previous glory and lustre, mentioned along with the prehistoric creatures that disappeared a very long time ago. Moving further and further in the past, the author clearly points to the obsoleteness of the colonial British rule, having no place in the modern times.

The author is linking the Crystal Palace and the relationship of the main couple directly in her novel, already when they moved into their new home while their relationship was still steady and successful as "... they had crossed the river Thames from north to south via Vauxhall bridge, headed for their first house" (Evans 2018: 6) in their car that is completely filled up with all their possessions " ... the boxes of books, the cassette tapes and vinyl, the clothes, the Cuban moka pot and 
the Czech marionette, an indigo painting of dancers at twilight, another of birds in Tanzania, the ebony mask from Lekki Market in Lagos, the Russian dolls, the Dutch pot, the papasan, the framed photographs of Erykah Badu, Fela Kuti and other heroes, the zigzag table lamp, the kitchenware..." (Evans 2018: 6-7). The things Melissa and Michael own and take with them to a new home are collectibles from different countries around the world, posing as a miniature version of the showcase for the Great World Exhibition in 1851. Their moving house is again paralleled in the description of the relocation of the Crystal Palace, also being transported from north to south London: "And approximately one hundred and fifty-six years before that ... south it went, to shine and show off at a margin ... the exotic wares of distant lands. Over the river came mummies. There was velvet, hemp and Belgian lace. There were bedsteads from Vienna, and majolica and terracotta, and awesome blocks of Welsh gold... down they went through Lambeth into Lewisham..." (Evans 2018: 7). Much more luxurious items, worthy of an Empire, were carried by horse-drawn carriages across London. Ordinary people like Melissa and Michael equally treasure their belongings that they want to take with them into their own palace of a smaller scale. Although more than a century apart, both translocations are intertwined in the narration and their connection in the novel is underlined as the carriages stopped "... in the vast expanse of the edgy green that came to be known as Crystal Palace Park, the distant peaks of which were now disappearing in the back windscreen of the red Toyota saloon" (Evans 2018: 7) and the landscape from the past is now seen from the main characters' car. London in the novel is portrayed as a bricolage of personal and public histories. Even at the beginning of their relationship, when Melissa and Michael were deeply in love and just started living together in a council flat but already their happiness is magnified into the grandeur of a castle, evoking the name of Crystal Palace: "The tower block became the palace in the sky. It glittered like the lesser Eiffel at night" (Evans 2018: 79). Moreover, its shine is compared to 'lesser Eiffel', not only referring to another exquisite example of the late $19^{\text {th }}$ century European architecture but also a transmitting tower located in the present-day Crystal Palace area, mentioned several times in the novel.

The neighbourhood they moved into is described in the novel: "On the high street there were six hairdressers, five chicken takeaways, four pound shops, five charity shops, three West Indian takeaways, two pawnbrokers, a tattooist, a Nigerian printers, and a selection of dingy workman's cafés. Starbucks and Caffè Nero had not yet arrived and possibly never would, though there was an air of aspiration" (Evans 2018:9). The shops featured in the main street in the area, especially the number of thrift stores and pawnbrokers, are the tell-tale sign of the socio-economic profile of the local inhabitants, this is still a mostly working-class part of London where gentrification has not yet affected the area. In addition, there is evident presence of postcolonial diaspora, 
West Indian and Nigerian, which again harks back to the times of the British Empire and the Great Exhibition in the Crystal Palace showcasing the colonized nations in London in the $19^{\text {th }}$ century, who have become Londoners since then.

Melissa and Michael go to a party dedicated to the Barack Obama's electoral victory in the late 2008. That is the first party they have attended in a long period of dedicating themselves to raising a small girl and a baby boy and there is finally an opportunity to have the night only to themselves. However, it becomes evident they have become emotionally and physically even more distant as a couple. The description of the scene in their bedroom is zooming out onto the streets around their house and further down on the Crystal Palace as an omen: "The palace was no longer standing. It had burnt to the ground in 1936, after a long and steady decline" (Evans 2018: 27). The main protagonists' relationship and their love are mirrored in the condition of the Crystal Palace that was doomed to be destroyed in the future.

When they decide to go out again, they become more connected with the Crystal Palace as they are using the eponymous train station: "When Crystal Palace was still standing, when people had come from miles and miles to see the colossi of Abu Simbel and the tomb of Beni Hassan, there had been two ways to get there, via the High Level line or the Low Level line. The High Level line was no longer in use; it was the Low Level platform on to which Melissa and Michael disembarked ..." (Evans 2018: 149). The chronotope (Bakhtin 2011) of Crystal Palace is thus multi-layered, there is the present time of the novel set in the years 2008 and 2009, and the past when visitors still were coming to see the palace toward the end of the $19^{\text {th }}$ century. The parallel existence of two periods in this place is further strengthened by the continuing description of their trip by underground train as if entering another dimension by “... climbing many steps up to the street after a rustling, verdant journey (the foliage thickens and closes in around the tracks along the way, as if you are going into a different world)" (Evans 2018: 140). The city is perceived as a palimpsest of its colonial past and postcolonial present, presented in the flâneurie of the main characters.

After another failed attempt at saving their relationship, Melissa and Michael are compared to the landmarks in their neighbourhood: "In the distance the towers were half cut by a thick fog that had descended, smothering their peaks, so that they were half of themselves. And this man and woman sitting in the back of the cab were just like those two towers, in their distance from one another, their separateness, he was Beulah and she was Crystal, and there seemed no way, in this fog, in this pretence, that they might come as one" (Evans 2018: 155). The fog is diminishing visibility, they are unable to see each other anymore and it seems they are not what they used to be - half of themselves. There is emptiness growing between the couple - their separateness, they cannot talk to each other, all communication is prevented, 
as if those telecommunication towers stopped functioning completely. Thus, the main protagonists' narrative intertwines with the urban metaphor of their emotions.

\section{No place like home}

The house Melissa and Michael bought together to move in with their children is at the address 13 Paradise Row near Crystal Palace. In addition to the obvious simultaneous optimistic and ominous symbolism of the name and the number of the street, their family home is "... a slim, white Victorian, with a skinny front door and twins of windows. Inside, at the top of the narrow staircase there was a skylight... The rooms were bright though small, and had a slight crooked quality... The hallway was not wide enough for two people to walk along side by side" (Evans 2018: 10). Gaston Bachelard notes that: "A house constitutes a body of images that give mankind proofs or illusions of stability" (Bachelard 1994: 17), thus their house could be perceived as maybe small but potentially cosy and domestic. However, at the entrance of the house, it is already indicated that there will not be enough space for a couple to continue their life together. Since "... both room and house are psychological diagrams that guide writers and poets in their analysis of intimacy" (Bachelard 1994: 38), later in the novel Melissa and Michael will be described as only occupying the same small space: "They lived in two different houses in one small one" (Evans 2018: 71). As they grew apart as a couple, Michael was cheating on Melissa and eventually confessed it to her. He moved out of their house but kept visiting the children. The carefully maintained balance turned into evident instability in their house and relationship. During this period, Michael was staying at a hotel with “... the reception desk had the feel of a motel or an airport stop-off" (Evans 2018: 225). The place he moved into is a typical 'non-place' according to Marc Augé (2008), completely impersonal and only functional, standing in a stark contrast with the emotions such as closeness and comfort connected to the home he left. When they reconciled after months of separation and he moved back in with his family again, it seemed that they could not be affected by the doom of Crystal Palace anymore: "Now they were travelling, high over Bell Green, high above the towers, away from the city" (Evans 2018: 236).

\section{Getting on (or not) like a house on fire}

Although they got back together, Melissa still feels the pressure of motherhood and taking care of their small children while Michael is at his company in the city centre. Thinking about her own career makes her even more depressed. She used to work as a fashion journalist and for a while she thought she could work from home as a freelancer. When she decides to return to the office of the magazine, her manager 
has to refuse her request due to a very bad financial situation. On her way back home, Melissa “... missed her stop, ending up in Crystal Place ... Not far from the base of the transmitting tower, she found a headless woman in the grasses, a broken statue from the days of glory. Melissa felt connected to the statue. She empathised with it" (Evans 2018: 286). Heavily disappointed by the missed opportunity to change her life, Melissa becomes disorientated in space as well. The state of the statue is relatable to Melissa, it is 'headless', which is the way she felt when she had lost her head and it represents the loss of both her sanity and intellect. She felt that she needed to be occupied by more than bringing up her children, but since she could not write magazine articles any longer, she was unable to restore her successful career as a journalist, and thus the 'days of glory' that used to be hers were now shattered to pieces.

Even though they started living together again, Melissa remains unhappy and she has an affair with Michael's friend one night. It does not mean anything to her, but it deepens the continuous distancing from Michael. She is withdrawing from their relationship, their closeness cannot be restored and their direction towards divorce cannot be reversed, which is again reflected in the description of the destruction of the Crystal Palace: "After an awful, empty moment, she extracted from him... She was not there... She did not put her bracelets anymore, her rings. She was nowhere in sight. The mummies in the Egyptian Court were vanishing. The statues in the Roman Court were withering. The flowers at the entrance to the Assyrian Court were dying. The arches of the Medieval Court were splintering" (Evans 2018: 291). The amazing appeal of the attractions in Crystal Palace is more and more absent in the same way as Melissa is detaching from Michael, not caring about her looks anymore. When she admits cheating on him, they have a fight, involving accusing and pushing each other and the restlessness is resonating in Crystal Palace from the past to the present day: "The bulls of the Assyrian Court were stamping. The lions in the Alhambra Court were roaring" (Evans 2018: 300). The tension is rising: "The monkeys in the monkey house were screaming. The parrots in the parrot house were shrieking" (Evans 2018: 303), as Melissa and Michael are shouting at each other.

Their fight culminates in an accident, their daughter falls down the stairs, but Michael catches her. Melissa runs out of the house and leaves them. The end of their relationship is depicted as the definite demise of Crystal Palace:

... the sculptures in the Grecian Court were crumbling, the tiles in the Moorish Court were cracking, the frescoes on the ceilings of the Renaissance Court were dissolving ... and the ferro-vitreous edges of the ferro-vitreous arches were loosening, and the heads of the statues of the Greeks in the grasses were rolling, and the dinosaurs made of old science 
were groaning, the spirals of the spiral staircases were spinning, the mummies in the Egyptian Court were wailing, the echoes in the organ loft were deafening, the big glass panes of the central transept were crashing And it was there, in the central transept, that on that cold November night in 1936, the final fire started (Evans 2018: 308).

All the symbols recurring in the narrative, ruined sculptures, broken walls, upset animals, the noise and the collapse that indicated the damage and decay but also foreshadowed the end of the Crystal Palace are completely destroyed by flames at the end of the novel. Crystal Palace as a toponym denotes grandeur but also fragility and it can be interpreted as a metaphor of both love and break up between Melissa and Michael. As the exhibition attracted numerous visitors, now their relationship is open to another audience, the readers of the novel Ordinary People.

\section{References}

Allardice, L. (2018). Diana Evans Interview: 'There's a ruthlessness in me towards writing'. The Guardian Online. (21 September 2019)<https://www.theguardian. com/books/2018/mar/19/diana-evans-interview-ordinary-people>.

Amin, A. and N. Thrift (2013). Cities: Reimaging the Urban. Cambridge and Malden, MA: Polity Press.

Augé, M. (2008) [1992]. Non-Places: An Introduction to Supermodernity, trans. by J. Howe. London and New York: Verso.

Bachelard, G. (1994) [1958]. The Poetics of Space: The Classic Look at How We Experience Intimate Places, trans. by M. Jolas. Boston: Beacon Press.

Bakhtin, M. M. (2011) [1975]. The Dialogic Imagination, trans. by M. Holquist. Austin: University of Texas Press.

Evans, D. (2018). Ordinary People. London: Chatto \& Windus. 